\title{
Role of endothelin receptor signalling in squamous cell carcinoma
}

\author{
SHUNSUKE ISHIMOTO $^{1,2}$, KOICHIRO WADA $^{1}$, NORIAKI TANAKA ${ }^{2}$, TADASHI YAMANISHI $^{2}$, \\ KOHJI ISHIHAMA ${ }^{2}$, TOMONAO AIKAWA ${ }^{2}$, MASAYA OKURA ${ }^{2}$, ATSUSHI NAKAJIMA ${ }^{3}$, \\ MIKIHIKO KOGO $^{2}$ and YOSHINORI KAMISAKI ${ }^{1}$ \\ ${ }^{1}$ Department of Pharmacology and ${ }^{2}$ The First Department of Oral and Maxillofacial Surgery, Graduate School \\ of Dentistry, Osaka University, 1-8 Yamadaoka, Suita, Osaka 565-0871; ${ }^{3}$ Department of Gastroenterology, \\ Yokohama City University School of Medicine, 3-9 Fuku-ura, Yokohama 236-0004, Japan
}

Received September 12, 2011; Accepted October 27, 2011

DOI: 10.3892/ijo.2011.1258

\begin{abstract}
Endothelin plays important roles in various physiological functions including vascular constriction. Recent studies reported that the endothelin receptors $\mathrm{ET}_{\mathrm{A}}$ and $\mathrm{ET}_{\mathrm{B}}$ are highly expressed in lung and skin tumor tissues. In contrast, there are few reports on endothelin signalling in the proliferation of head and neck cancer. We found that both $\mathrm{ET}_{\mathrm{A}}$ and $\mathrm{ET}_{\mathrm{B}}$ endothelin receptors were overexpressed in tumor cells of tongue cancer samples by immunohistochemistry. $\mathrm{ET}_{\mathrm{A}}$ and $\mathrm{ET}_{\mathrm{B}}$ were expressed in cultured lingual and esophageal squamous cell carcinoma (SCCs) cell lines. When both cultured cell lines were treated with an $\mathrm{ET}_{\mathrm{A}}$ selective antagonist (BQ123) or an $\mathrm{ET}_{\mathrm{B}}$ selective antagonist (BQ788), inhibition of cell growth was observed. Similar results were observed when SCCs were treated with specific siRNA for the suppression of $\mathrm{ET}_{\mathrm{A}}$ or $\mathrm{ET}_{\mathrm{B}}$. Furthermore, inhibition of the mitogen-activated protein (MAP) kinase pathway by the treatments with ET receptor antagonists and siRNA was also observed. These results indicate that endothelin signalling may, in part, play important roles in cell growth in SCCs through the MAP kinase pathway.
\end{abstract}

\section{Introduction}

Endothelin (ET) plays important roles on various physiological functions including vascular constriction (1-4). ET family comprises three isoforms, ET-1, ET-2, and ET-3, that bind to two receptor subtypes, endothelin $\mathrm{A}\left(\mathrm{ET}_{\mathrm{A}}\right)$ and endothelin $\mathrm{B}$ $\left(\mathrm{ET}_{\mathrm{B}}\right)$ receptors (1-4). Recent studies reported that $\mathrm{ET}_{\mathrm{A}}$ and $\mathrm{ET}_{\mathrm{B}}$ were highly expressed on lung, colon and skin cancers (5-7). In addition, several reports suggested that ET-1 plays important roles in tumorigenesis, tumor progression, and metastasis

Correspondence to: Dr Shunsuke Ishimoto, Department of Pharmacology, Graduate School of Dentistry, Osaka University, 1-8 Yamadaoka, Suita, Osaka 565-0871, Japan

E-mail: ishimoto@dent.osaka-u.ac.jp

Key words: squamous cell carcinoma, tongue, cellular proliferation, endothelin receptor, MAP kinase signaling pathway
(8-10). Thus, the ET receptors and their signalling pathways may be a therapeutic target in cancer therapy (11). However, little is known about the role of ET signalling on tumor cell proliferation of oral squamous cell carcinoma (SCC).

Human SCC is major neoplasm in esophagus or oral cavity and the incidence has recently been increasing (12-14). The optimal treatment for early carcinoma of oral cavity is surgical operation. However, overall survival remains largely unchanged (12-14). In addition, the decrease in quality of life (QOL) after wide excision of tongue is also important issue for patients. Therefore, different therapies are required. In our previous studies, we investigated the whole genome analysis using DNA microarray to find the potential target genes involved in tumor cell growth, and reported the critical role of several important molecules on the cell growth of SCCs (15-19). According to the results of DNA microarray, we found increased expression of ET receptor mRNA in cell lines of oral SCCs and the alteration of expression level on SCC growth $(15,18,19)$. Therefore, we have examined whether ET receptors may be expressed in primary oral SCC tissues, and whether ET receptor-signalling may play a critical role of SCC growth. Our results imply a potentially important and novel role of ET function on SCC growth, and suggest that ET receptor-signalling might be useful target in the therapy of SCCs.

\section{Materials and methods}

Tissue samples. All of clinical studies were approved by the Ethics Committee of Osaka University Dental Hospital. Twentythree samples of squamous cell carcinoma (SCC) located in the tongue were obtained from surgical resection tissue specimens at Osaka University Dental Hospital after informed consent was obtained. The patients, who received no preoperative therapy including chemotherapy and irradiation therapy, were randomly selected (Table I). The age range was 33-92 years (average: $62.0 \pm 13.9$ years, mean $\pm \mathrm{SD}$ ).

Chemicals and antibodies. ET receptor specific antagonists, $\mathrm{BQ123}$ for $\mathrm{ET}_{\mathrm{A}}$ and $\mathrm{BQ788}$ for $\mathrm{ET}_{\mathrm{B}}$ were purchased from Sigma-Aldrich Japan (Tokyo, Japan). Anti-ET $\mathrm{A}_{\mathrm{A}}$ or $\mathrm{ET}_{\mathrm{B}}$ polyclonal antibody was from Acris (Acris, Herford, Germany). Antibodies against Focal adhesion kinase (FAK), phosphorylated FAK, 
Table I. Profile of lingual squamous cell carcinoma patients, their histological diagnosis and expression of $\mathrm{ET}_{\mathrm{A}}$ and $\mathrm{ET}_{\mathrm{B}}$ in tissue sections.

\begin{tabular}{|c|c|c|c|c|c|c|}
\hline \multirow[b]{2}{*}{ Case } & \multirow{2}{*}{$\begin{array}{c}\text { Age/ } \\
\text { Gender }\end{array}$} & \multirow[b]{2}{*}{ Differentiation } & \multicolumn{2}{|c|}{$\mathrm{ET}_{\mathrm{A}}$ expression } & \multicolumn{2}{|c|}{$\mathrm{ET}_{\mathrm{B}}$ expression } \\
\hline & & & Tumor area & Non-tumor area & Tumor area & Non-tumor area \\
\hline 1 & $71 / \mathrm{F}$ & Well differentiated SCC & +++ & + & +++ & ++ \\
\hline 2 & $57 / \mathrm{M}$ & Well differentiated SCC & + & N/A & ++ & N/A \\
\hline 3 & $69 / \mathrm{M}$ & Well differentiated SCC & ++ & N/A & +++ & N/A \\
\hline 4 & $64 / M$ & Well differentiated SCC & +++ & + & +++ & ++ \\
\hline 5 & $46 / \mathrm{F}$ & Well differentiated SCC & ++ & + & +++ & + \\
\hline 6 & $61 / \mathrm{M}$ & Well differentiated SCC & + & N/A & + & N/A \\
\hline 7 & $48 / \mathrm{M}$ & Well differentiated SCC & ++ & N/A & +++ & N/A \\
\hline 8 & $72 / \mathrm{M}$ & Well differentiated SCC & ++ & N/A & +++ & N/A \\
\hline 9 & $79 / \mathrm{M}$ & Well differentiated SCC & ++ & N/A & ++ & N/A \\
\hline 10 & $68 / \mathrm{M}$ & Moderately differentiated SCC & +++ & N/A & +++ & N/A \\
\hline 11 & 64/M & Moderately differentiated SCC & ++ & + & +++ & ++ \\
\hline 12 & $58 / \mathrm{F}$ & Moderately differentiated SCC & +++ & N/A & +++ & N/A \\
\hline 13 & $92 / \mathrm{F}$ & Moderately differentiated SCC & ++ & - & +++ & - \\
\hline 14 & $86 / \mathrm{F}$ & Moderately differentiated SCC & ++ & + & + & + \\
\hline 15 & $57 / \mathrm{M}$ & Moderately differentiated SCC & +++ & N/A & +++ & N/A \\
\hline 16 & $62 / \mathrm{M}$ & Moderately differentiated SCC & ++ & N/A & +++ & $\mathrm{N} / \mathrm{A}$ \\
\hline 17 & $52 / \mathrm{F}$ & Poor-moderately differentiated SCC & ++ & N/A & ++ & $\mathrm{N} / \mathrm{A}$ \\
\hline 18 & 38/M & Poorly differentiated SCC & + & - & ++ & + \\
\hline 19 & $51 / \mathrm{F}$ & Poorly differentiated SCC & ++ & - & ++ & + \\
\hline 20 & 67/M & Poorly differentiated SCC & ++ & N/A & ++ & $\mathrm{N} / \mathrm{A}$ \\
\hline 21 & $66 / \mathrm{M}$ & Poorly differentiated SCC & ++ & N/A & +++ & N/A \\
\hline 22 & $65 / \mathrm{M}$ & Poorly differentiated SCC & ++ & N/A & +++ & $\mathrm{N} / \mathrm{A}$ \\
\hline 23 & 33/M & Poorly differentiated SCC & ++ & - & +++ & + \\
\hline
\end{tabular}

Expression of $\mathrm{ET}_{\mathrm{A}}$ or $\mathrm{ET}_{\mathrm{B}}$ by immunohistochemical staining in tumor and non-tumor area is scored and expressed as (-) to (+++). N/A, not applicable.

phosphorylated MEK1/2, p44/42 MAPK (pErk1/2) phosphorylated p44/42 MAPK and anti-rabbit IgG (HRP-linked) for secondary antibody are from Cell Signalling Technologies (Beverly,MA). Cisplatin was from Wako Pure Chemical Industries, Ltd. (Osaka, Japan).

Immunohistochemical staining of $E T_{A}$ and $E T_{B}$. The expression of $\mathrm{ET}_{\mathrm{A}}$ or $\mathrm{ET}_{\mathrm{B}}$ in tissues was detected by anti-ET $\mathrm{E}_{\mathrm{A}}$ or $\mathrm{ET}_{\mathrm{B}}$ specific polyclonal antibody using standard immunohistochemical techniques on formalin-fixed and paraffin-embedded continuous sections. Incubation with anti-ET ${ }_{\mathrm{A}}$ or $\mathrm{ET}_{\mathrm{B}}$ polyclonal antibody was performed at $4^{\circ} \mathrm{C}$ for $16 \mathrm{~h}$, then the sections were washed out. After the application with secondary antibody, the Vectastain ABC kit (Vector Laboratories, Burlingame, CA) was used with a 3,3'-diaminobenzidine (DAB) substrate kit, according to the manufacturer's instructions. The staining endpoint was determined when the standard tissue sections were constantly stained to the intensity as described previously $(18,19)$.

The intensity of the immunohistochemical staining with anti-ET $\mathrm{Er}_{\mathrm{A}} \mathrm{ET}_{\mathrm{B}}$ antibody was evaluated by scoring the staining reaction in four groups: (-), none/weak; (+), weak/moderate; (++), moderate/strong, and (+++), very strong cytoplasmic staining intensity, respectively $(18,19)$. To check the reproducibility of the evaluation system concerning the immunohistochemical staining for the $\mathrm{ET}_{\mathrm{A}}$ and $\mathrm{ET}_{\mathrm{B}}$ proteins, another oral surgeon and pathologist who were unaware of the original assessment re-evaluated the results of staining according to the system above. Tumor areas were confirmed by both of the pathologist and surgeon under the microscopy. Non-tumor areas were selected, the comparatively normal areas were separated away from the tumor areas, and confirmed by the pathologist.

Cell culture. We used human oral SCC cell line (SAS) and human esophageal SCC cell line (KYSE70). SAS was established as tongue SCC and KYSE70 was established as esophageal SCC $(15,16)$. SAS was maintained in DMEM containing $10 \%$ fetal bovine serum (FBS), and KYSE70 was maintained in DMEM containing $2 \% \mathrm{FBS}$ at $37^{\circ} \mathrm{C}$ under $0.5 \% \mathrm{CO}_{2}$. For cell growth experiment, cells were trypsinized and replated onto culture dishes (15-19).

Cell survival assay using ET receptor antagonists. SCC cells were treated with ET receptor antagonists, $\mathrm{BQ} 123$ for $\mathrm{ET}_{\mathrm{A}}$ and 
A

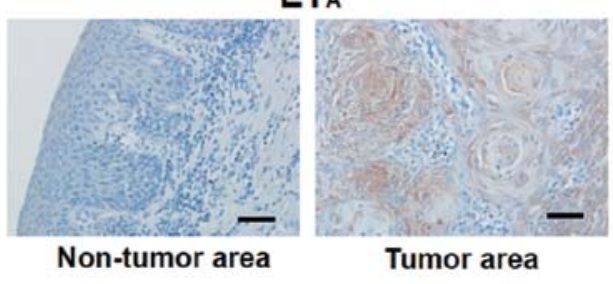

C

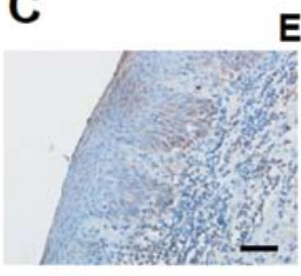

Non-tumor area
$E T_{A}$

Tumor area

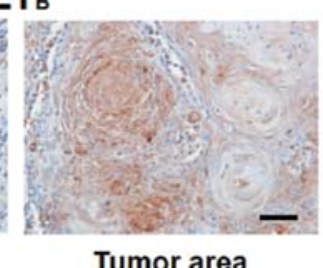

Tumor area
B

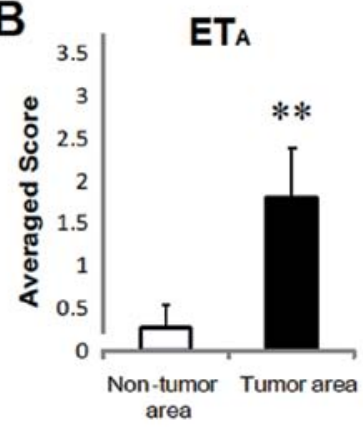

D

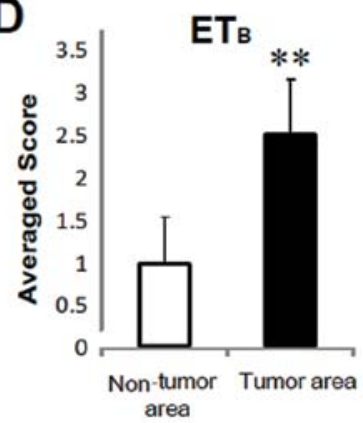

E

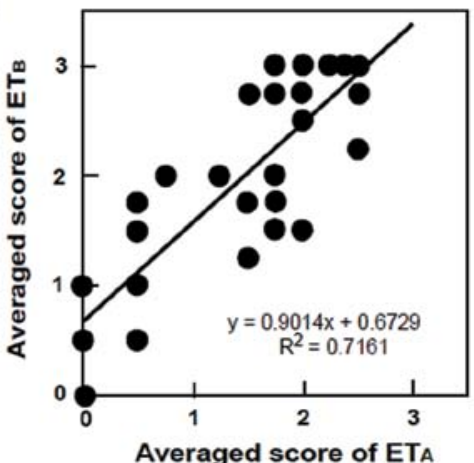

Figure 1. Expression of $\mathrm{ET}_{\mathrm{A}}$ or $\mathrm{ET}_{\mathrm{B}}$ on tumor cells in lingual tissues. (A) $\mathrm{ET}_{\mathrm{A}}$ expression on tumor area (right panel) of primary lingual squamous cell carcinoma and non-tumor area (left panel) in the same tissue section (case 13 in Table I) by immunohistochemical observations. The brown color represents positive staining of $\mathrm{ET}_{\mathrm{A}}$ and the blue represents counterstaining. Scale bar represents $100 \mu \mathrm{m}$. (B) Comparison of the expression of $\mathrm{ET}_{\mathrm{A}}$ between tumor area and non-tumor area. Averaged score of strengthen of $\mathrm{ET}_{\mathrm{A}}$ expression are expressed from the data in Table I. Each column represents mean $\pm \mathrm{SEM}$ from 9-23 cases in tumor area or non-tumor area, respectively. ${ }^{* *} \mathrm{P}<0.01$. (C) $\mathrm{ET}_{\mathrm{B}}$ expression on tumor area (right panel) of primary lingual squamous cell carcinoma and non-tumor area (left panel) in the same tissue section (case 13 in Table I) by immunohistochemical observations. The brown color represents positive staining of ET ${ }_{\mathrm{B}}$ and the blue represents counterstaining. Scale bar represents $100 \mu \mathrm{m}$. (D) Comparison of the expression of ET $_{\mathrm{B}}$ between tumor area and non-tumor area. Averaged score of strengthen of $\mathrm{ET}_{\mathrm{B}}$ expression are expressed from the data in Table I. Each column represents mean \pm SEM from 9-23 cases in tumor area or non-tumor area, respectively. ${ }^{* * *} \mathrm{P}<0.01$. (E) Correlation between $\mathrm{ET}_{\mathrm{A}}$ and $\mathrm{ET}_{\mathrm{B}}$ expression. Each point represents each individual.

BQ788 for $\mathrm{ET}_{\mathrm{B}}$ for 24 and $48 \mathrm{~h}$ in culture medium. Then, cell viability was measured 24 and $48 \mathrm{~h}$ after the treatment using Countess Automated Cell Counter (Invitrogen, Eugene, OR). The inhibition of cell growth was compared to vehicle-treated control.

RNA interference approach. SAS and KYSE70 were trypsinized and resuspended in DMEM without FBS, and the cells were separated approximately $1 \times 10^{5}$ cells for each dish. The $\mathrm{ET}_{\mathrm{A}}$ and $\mathrm{ET}_{\mathrm{B}}$-specific siRNA (Stealth siRNA) were purchased from Invitrogen Japan (Tokyo, Japan). The sequence of the sense strand of $E_{A^{-}}$-siRNA is 5'-UUUGAUGUGGCAUUGAGCAUACAGG-3', and antisense is 5'-CCUGUAUGCUCAAUGCCACAUCAAA-3', respectively. The sequence of the sense strand of $\mathrm{ET}_{\mathrm{B}}$-SiRNA is 5'-UAAUUCUACUCCAAGAAGCAACAGC-3', and antisense is 5'-GCUGUUGCUUCUUGGAGUAGAAUUA-3', respectively. For the transfection, $\mathrm{ET}_{\mathrm{A}}, \mathrm{ET}_{\mathrm{B}}$-siRNA $(40 \mathrm{nM})$ or negative control (40 nM Stealth RNAi Negative Control Duplexes, Invitrogen Japan Inc.) solution was added to DMEM medium containing Lipofectamine RNAiMax (Invitrogen Japan) and allowed to incubate for $20 \mathrm{~min}$ at room temperature to create the transfection mixture. The transfection mixture was then added to the cells at the indicated final concentration of siRNA. Twenty-four hours after the transfection, the medium was changed to DMEM containing 10\% FBS for SAS and 2\% FBS for KYSE70. Then, viable cell number was measured 24 and $48 \mathrm{~h}$ after the medium change using Countess Automated Cell Counter. The cell growth was expressed as the percentage to that of vehicle control. 
A

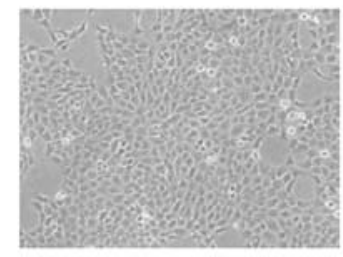

Control

\section{SAS}

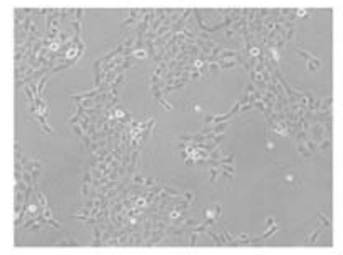

$\mathrm{BQ123}(10 \mu \mathrm{M})$

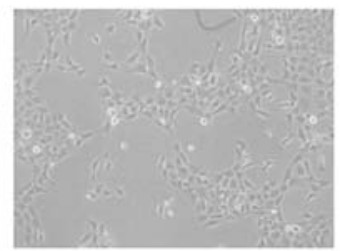

$\mathrm{BQ788}(10 \mu \mathrm{M})$

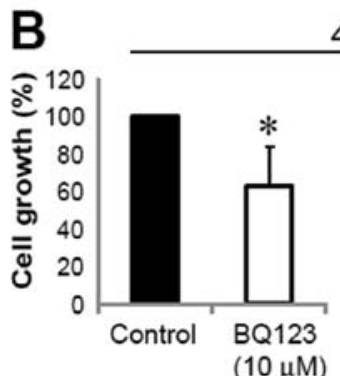

$48 \mathrm{~h}$
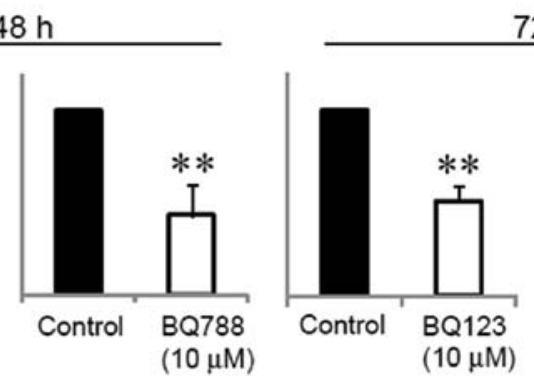

$72 \mathrm{~h}$

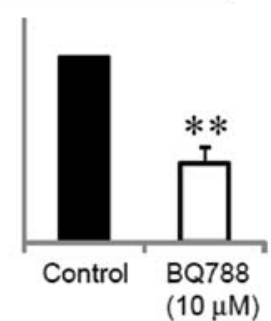

C

\section{KYSE70}

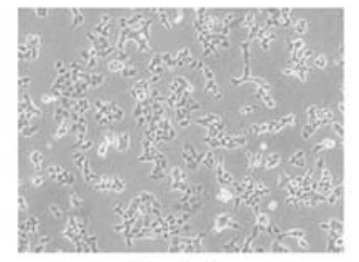

Control

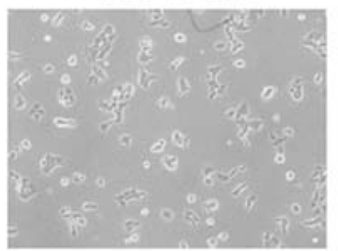

BQ123 $(10 \mu \mathrm{M})$

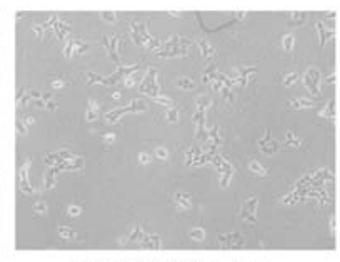

BQ788 $(10 \mu \mathrm{M})$

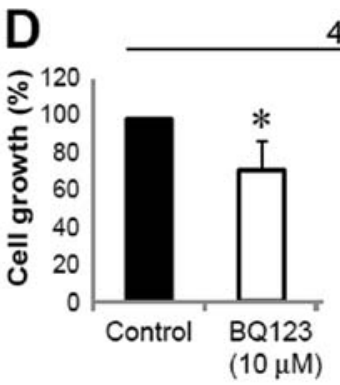

$48 \mathrm{~h}$

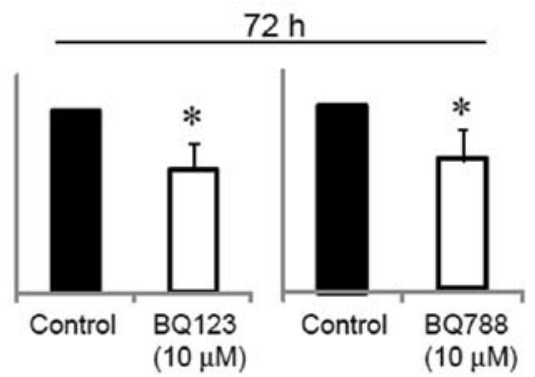

Figure 2. Effects of ET receptor antagonists on $\mathrm{SCC}$ cell growth. (A and B) Effect of $\mathrm{ET}_{\mathrm{A}}$ antagonist, $\mathrm{BQ123}$ or $\mathrm{ET}_{\mathrm{B}}$ antagonist, $\mathrm{BQ788}$ on cell growth of SAS. Typical images (A) and cell growth rate (B). 48 and $72 \mathrm{~h}$ after the start of treatment, viable cell number was counted and cell growth rate was expressed. Each column represents the percentage of cell growth (mean \pm SEM from 4-5 independent experiments) compared to vehicle control (black column, PBS). Error bars represent standard deviations. ${ }^{* * *} \mathrm{P}<0.01,{ }^{*} \mathrm{P}<0.05$ vs. negative control. (C and D) Effect of $\mathrm{ET}_{\mathrm{A}}$ antagonist, BQ123 or ET $\mathrm{B}_{\mathrm{B}}$ antagonist, $\mathrm{BQ788}$ on cell growth of KYSE70.

Western blot analysis. Adherent or suspended cells were washed in PBS, and cell extracts were prepared by lysing cells in lysis buffer. The proteins were separated by electrophoresis using $10 \%$ SDS-PAGE, and transferred to nitrocellulose membrane (Millipore, Bedford,MA). Detection of proteins were performed by each polyclonal antibody and visualized by using the ECL detection kit (Amersham, London, UK) following the manufacturer's suggested procedure.

Combination of $E T_{A}, E T_{B}$-siRNA and anti-tumor drug. Combined treatment of $\mathrm{ET}_{\mathrm{A}}, \mathrm{ET}_{\mathrm{B}}$-siRNA with anti-tumor drug, cisplatin, was performed. Briefly, after the low concentration of $\mathrm{ET}_{\mathrm{A}}$ or $\mathrm{ET}_{\mathrm{B}}$-siRNA $(20 \mathrm{nM})$ treatment, $2.5 \mu \mathrm{M}$ of cisplatin that was a concentration slightly effective on cell growth inhibition was treated for $48 \mathrm{~h}$. Cell growth was measured by Countess Automated Cell Counter and expressed as percentage.

Statistical analysis. All results are expressed as mean \pm SEM. Statistical comparisons were made using the Student-t test or Scheffe's method after analysis of variances (ANOVA). The results were considered significantly different at $\mathrm{P}<0.05$.

\section{Results}

Lingual SCCs in tumor tissues express $E T_{A}$ and $E T_{B}$. Lingual SCC primary tissues were stained using anti-ET $\mathrm{A}_{\mathrm{A}}$ or anti-ET $\mathrm{E}_{\mathrm{B}}$ specific antibody, respectively. Positive staining of $\mathrm{ET}_{\mathrm{A}}$ was 
A

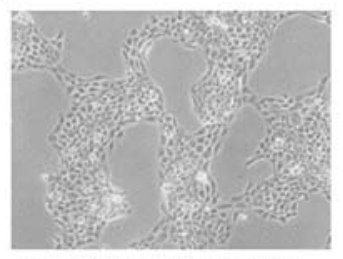

Negative control-siRNA

\section{SAS}

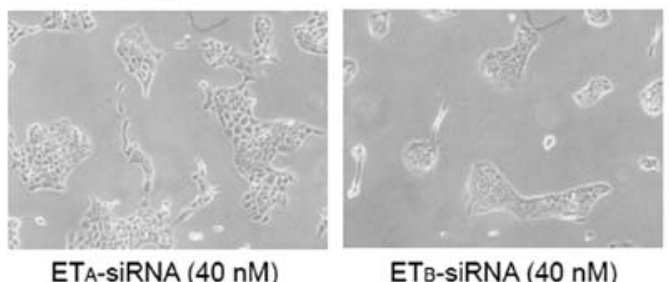

ETB-siRNA (40 nM)

B
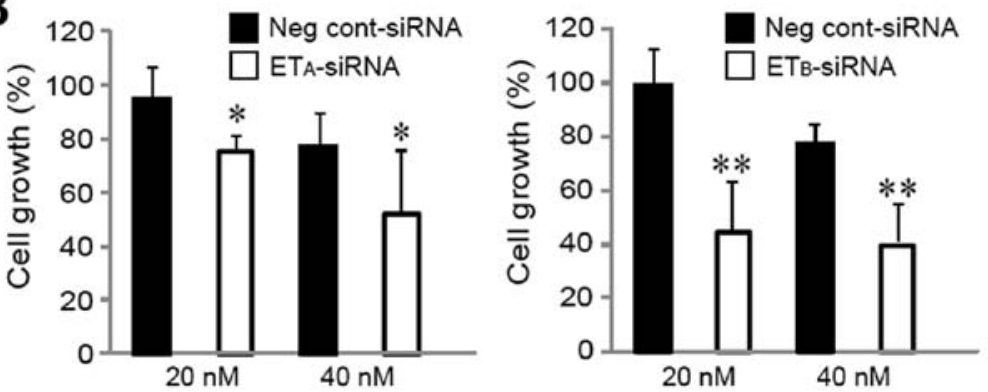

C

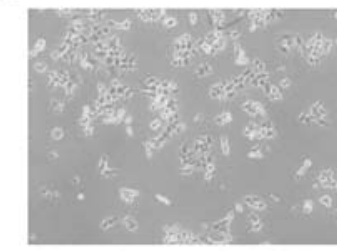

Negative control-siRNA

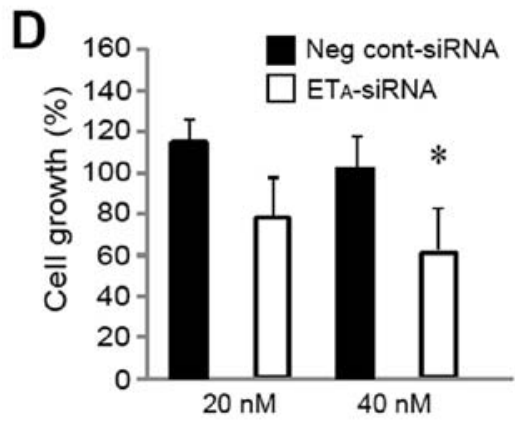

KYSE70

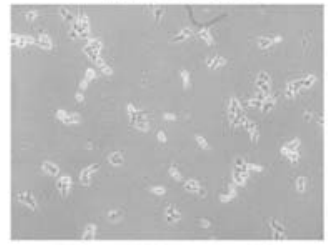

ETA-siRNA (40 nM)

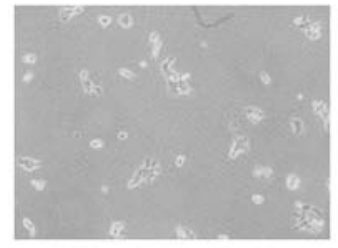

ETB-siRNA (40 nM)

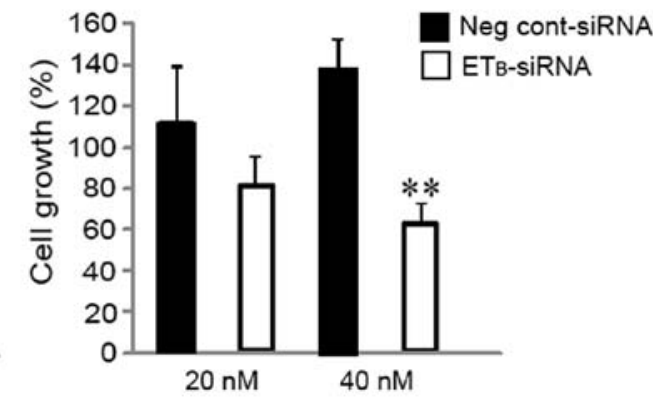

Figure 3. Effects of ET receptor knockdown on the cell growth of SCCs treated with $\mathrm{ET}_{\mathrm{A}}$ or $\mathrm{ET}_{\mathrm{B}}$-siRNA. (A and B) Effects of $\mathrm{ET}_{\mathrm{A}}$-siRNA or $\mathrm{ET}_{\mathrm{B}}$-siRNA on cell growth of SAS. Typical images (A) and cell growth rate (B). Cells were transfected the siRNA ( $40 \mathrm{nM})$ for $24 \mathrm{~h}$ and cultured for additional $48 \mathrm{~h}$, followed by viable cell counting. Each value represents the percentage of cell growth compared with vehicle (non-siRNA) control from 4-7 independent experiments. White column represents the growth of cells transfected with $\mathrm{ET}_{\mathrm{A}}$ (left panel) or $\mathrm{ET}_{\mathrm{B}}$ (right panel)-siRNA and black column represents that of cells transfected with negative control-siRNA, respectively. Error bars represent standard deviations. ${ }^{* *} \mathrm{P}<0.01,{ }^{*} \mathrm{P}<0.05$ vs. negative control. (C and D) Effects of $\mathrm{ET}_{\mathrm{A}}$-siRNA and ET $\mathrm{B}_{\mathrm{B}}$-siRNA on cell growth of KYSE70. Typical photos (C) and cell growth rate (D). Cells were transfected the siRNA ( $40 \mathrm{nM})$ for $24 \mathrm{~h}$ and cultured for additional $48 \mathrm{~h}$, followed by viable cell counting. Each value represents the percentage of cell growth compared with vehicle (non-siRNA) control from 4 independent experiments. White column represents the growth of cells transfected with $\mathrm{ET}_{\mathrm{A}}$ (left panel) or $\mathrm{ET}_{\mathrm{B}}$ (right panel)-siRNA and black column represents that of cells transfected with negative control-siRNA, respectively. Error bars represent standard deviations. ${ }^{* *} \mathrm{P}<0.01,{ }^{*} \mathrm{P}<0.05$ vs. negative control.

observed in tumor area (Fig. 1A, right). In contrast, none of staining of $\mathrm{ET}_{\mathrm{A}}$ was observed in non-tumor area in the same tissue section (Fig. 1A, left). Similar staining pattern was also observed in other tumor tissue sections (Table I). Statistically significance of the $\mathrm{ET}_{\mathrm{A}}$ expression between tumor and nontumor area was observed (Fig. 1B). In addition, positive staining of $\mathrm{ET}_{\mathrm{B}}$ in tumor area, but not non-tumor area, was also observed in the same tissue section (Fig. 1C). Statistical significance of the $\mathrm{ET}_{\mathrm{B}}$ expression between tumor and nontumor areas was also observed (Fig. 1D and Table I). These results are similar to that of $\mathrm{ET}_{\mathrm{A}}$. Good correlation between $\mathrm{ET}_{\mathrm{A}}$ and $\mathrm{ET}_{\mathrm{B}}$ expression was observed (Fig. 1E).

ET receptor antagonists suppress cell growth of lingual and esophageal SCC. According to the data of ET receptor expression in SCCs, we hypothesized that ET receptor-signalling might play an important role on the cell growth of SCCs. To investigate the hypothesis, we used ET receptor antagonists, $\mathrm{BQ} 123$ for $\mathrm{ET}_{\mathrm{A}}$ and $\mathrm{BQ788}$ for $\mathrm{ET}_{\mathrm{B}}$. As shown in Fig. 2A and B, ET receptor antagonists, BQ123 and BQ788 suppressed the cell growth of 
A

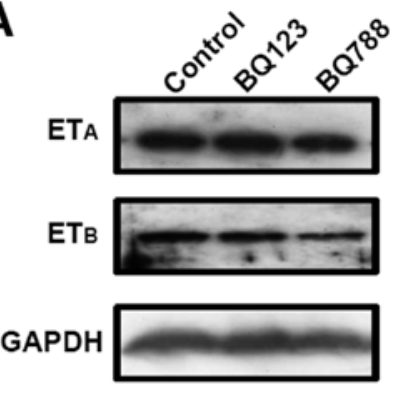

B

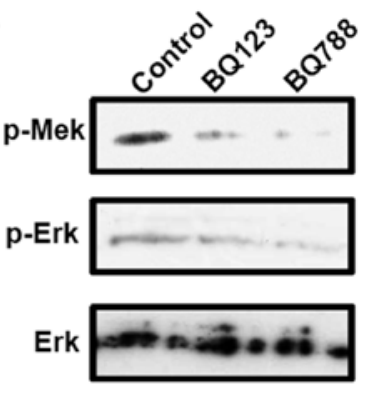

\section{C}

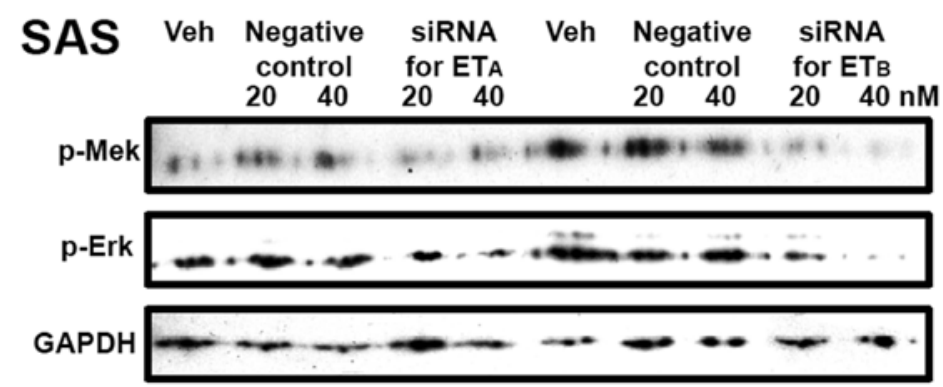

D

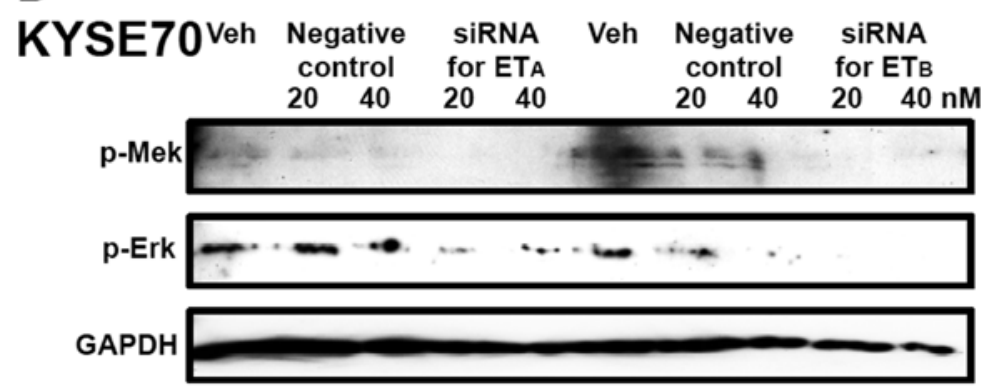

Figure 4. Involvement of MAPK pathway on ET receptor-signalling of SCC growth. (A) A Western blot analysis showing ET $_{\mathrm{A}}$ or ET $\mathrm{B}_{\mathrm{B}}$ expression in $\mathrm{SAS}_{\mathrm{S} \text { wich }}$ were pre-treated with $\mathrm{ET}_{\mathrm{A}}$ antagonist, BQ123, or $\mathrm{ET}_{\mathrm{B}}$ antagonist, BQ788. GAPDH is standard for equivalent application. No alteration was observed. (B) Suppression of MAPK pathway by ET receptor antagonists. SAS was treated with $\mathrm{ET}_{\mathrm{A}}$ antagonist, BQ123, or ET $\mathrm{B}_{\mathrm{B}}$ antagonist, BQ788, then the phosphorylation of Mek (p-MEK) or Erk (p-Erk) was detected for Western blot analysis. (C) Western blot analysis for expression of p-MEK and p-Erk by the treatment with ET or $\mathrm{ET}_{\mathrm{B}}$-siRNA on SAS. Cells were treated with $\mathrm{ET}_{\mathrm{A}}$ or $\mathrm{ET}_{\mathrm{B}}$-siRNA (20 and $40 \mathrm{nM}$ ), negative control siRNA and vehicle (Veh). Samples were collected for $24 \mathrm{~h}$ after the treatment. GAPDH was used to evaluate equivalent loading. (D) Western blot analysis for expression of p-MEK and p-Erk by the treatment with ET ${ }_{\mathrm{A}}$ or $\mathrm{ET}_{\mathrm{B}}$-siRNA on SAS. Cells were treated with $\mathrm{ET}_{\mathrm{A}}$ or $\mathrm{ET}_{\mathrm{B}}$-siRNA (20 and $40 \mathrm{nM}$ ), negative control siRNA and vehicle (Veh). Samples were collected $24 \mathrm{~h}$ after the treatment. GAPDH was used to evaluate equivalent loading.

lingual SCC cell line, SAS. The suppression by the antagonists was concentration- and time-dependent (data not shown).

In addition to the results of growth suppression of lingual SCC by the inhibition of ET receptors, both antagonists also suppressed the cell growth of esophageal SCC cell line, KYSE70 (Fig. 2C and D). These results indicate that ET receptor-signalling is required for the growth of SCCs.

$E T_{A}$ and $E T_{B}$-siRNA suppress cell growth of lingual and esophageal SCC. To clarify the exact function of ET receptors on the growth of SCCs, we used small interfering RNA (siRNA) for $\mathrm{ET}_{\mathrm{A}}$ and $\mathrm{ET}_{\mathrm{B}} \cdot \mathrm{ET}_{\mathrm{A}}$ and $\mathrm{ET}_{\mathrm{B}}$-siRNA effectively decreased the ET receptor protein levels in SCCs. The inhibition of cell growth on SAS was clearly observed when $\mathrm{ET}_{\mathrm{A}}$ or $\mathrm{ET}_{\mathrm{B}}$ was knocked down by the treatment with siRNA (Fig. 3A and B). Similar suppression of cell growth by the knockdown of $\mathrm{ET}_{\mathrm{A}}$ or $\mathrm{ET}_{\mathrm{B}}$ was also observed when esophageal SCC cell line, KYSE70 was treated with siRNA for $\mathrm{ET}_{\mathrm{A}}$ or $\mathrm{ET}_{\mathrm{B}}$ (Fig. 3C and D). These results clearly indicate that ET receptor-signalling is required for the growth of SCCs.

Investigation of potential mechanisms. We next investigated the mechanisms of inhibition of cell growth induced by the suppression of ET receptor-signalling. Western blot analysis showed the expression of $\mathrm{ET}_{\mathrm{A}}$ and $\mathrm{ET}_{\mathrm{B}}$ proteins on the lingual SCC cell line SAS (Fig. 4A). Although the specific antagonists blocked the $\mathrm{ET}_{\mathrm{A}}$ or $\mathrm{ET}_{\mathrm{B}}$ signalling, no alterations of receptor protein expression levels were observed (Fig. 4A). In contrast, blockade of ET receptor-signalling by the treatment with antagonists caused the suppression of phosphorylation of MEK and Erk (mitogen-activated protein kinase), the important members of MAPK pathway (Fig. 4B). In addition, similar suppression of MAPK pathway by knockdown of ET receptors was observed when SAS and KYSE70 were treated with $\mathrm{ET}_{\mathrm{A}}$ or $\mathrm{ET}_{\mathrm{B}}$-SiRNA 
A

SAS

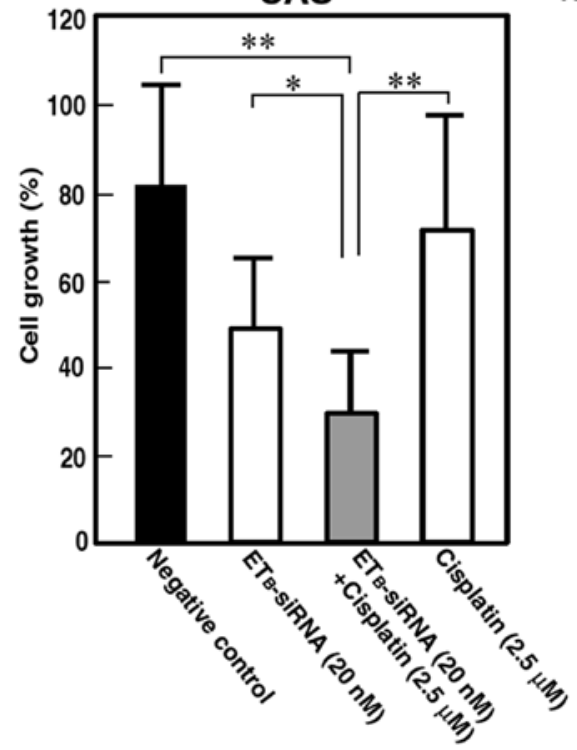

Negative control-siRNA

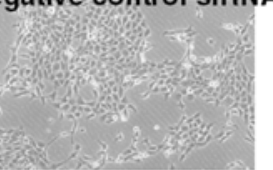

ETB-SIRNA

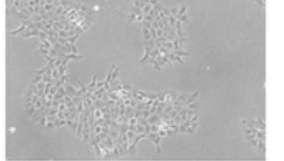

ETB-siRNA + Cisplatin

B ETA, B-siRnA

$\mathrm{ET}_{\mathrm{A}, \mathrm{B}}$-antagonists

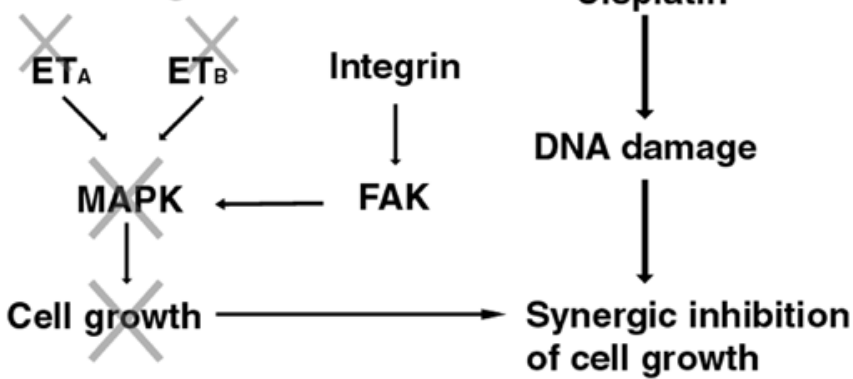

Figure 5. Combination therapy of $\mathrm{ET}_{\mathrm{B}}$-siRNA and anti-tumor drug. (A) Combined treatment of low dose of $\mathrm{ET}_{\mathrm{B}}$-siRNA $(20 \mathrm{nM})$ with cisplatin $(2.5 \mu \mathrm{M})$ was performed on cultured SCC cell line, SAS. Cells were treated with ET ${ }_{B}$-siRNA, negative control or vehicle for $24 \mathrm{~h}$, then, treated with cisplatin or vehicle for $48 \mathrm{~h}$. Each value represents the percentage of cell growth compared with vehicle (non-siRNA) control from 5 independent experiments. ${ }^{*} \mathrm{P}<0.05$, ${ }^{* *} \mathrm{P}<0.01$ vs. negative control, or each single treatment, respectively. (B) Schematic illustration of possible mechanisms on the inhibition of cell growth by the combination of ET receptor-siRNA with cisplatin.

(Fig. 4C and D). These results indicate the involvement of MAPK pathway on the ET receptor-signalling mediated cell growth of SCCs.

In contrast, no inhibition of phosphorylation of focal adhesion kinase (FAK), a 125 kDa non-receptor tyrosine kinase $(20,21)$, by the suppression of ET receptor signalling was observed (data not shown).

We also investigated the effect of blockade of ET receptorsignalling on expression of integrins such as integrin $\alpha 5$ and $\beta 1$ $(22,23)$. However, no alterations of integrin $\alpha 5$ and $\beta 1$ expressions were observed (data not shown). These results suggest that the cell growth suppression of SCCs by the knockdown or blockade of ET receptors is mediated through the direct inhibition of MAPK signalling pathway.

Combination therapy of $E T_{A}$ or $E T_{B}$-siRNA and anti-tumor drugs. Reduction of dosage of anti-tumor drugs for cancer chemotherapy is clinically important to minimize the side effects, although the complete tumor cell death is required. Combined treatment of $\mathrm{ET}_{\mathrm{B}}$-siRNA $(20 \mathrm{nM})$ with anti-tumor drug, cisplatin $(2.5 \mu \mathrm{M})$, drastically inhibited the cell growth of SAS in comparison to that in each single treatment (Fig. 5A). Similar results were also observed in the combined treatment of $\mathrm{ET}_{\mathrm{A}}$-siRNA (20 nM) with cisplatin (data not shown). These results indicate that combination therapy of $\mathrm{ET}_{\mathrm{A}}$ or $\mathrm{ET}_{\mathrm{B}}$-siRNA and ordinal anti-tumor drugs may be a novel and useful therapy for SCCs.

\section{Discussion}

There have been several reports on the expression of ET receptors in various human cancers (5-7), and it is considered to be the relationship between ET receptor-signalling and tumor cell growth. There are, however, few reports on the evaluation and investigation of the exact role of ET receptor-signalling using human SCC tissues and cultured cell lines of oral and esophageal carcinomas.

In the present study, using an immunohistochemical method, we demonstrated significantly higher levels of expression of $\mathrm{ET}_{\mathrm{A}}$ and $\mathrm{ET}_{\mathrm{B}}$ protein in human lingual cancer 
tissues than in non-tumor areas in the same tissue samples. Similar results were also observed on the cultured SCC cell lines such as SAS, lingual SCC, and KYSE70, esophageal SCC. These results indicate the involvement of ET receptor-signalling on SCC growth. Furthermore, we showed that the suppression of ET receptor protein by siRNA or the blockade by antagonists caused the inhibition of SCC growth. In our experimental conditions, both the treatment with $\mathrm{ET}_{\mathrm{A}}$ and $\mathrm{ET}_{\mathrm{B}}$ antagonists and siRNA strongly inhibited the cell growth of SCCs. These results strongly suggest the important role for ET receptor-signalling in SCC cell survival. In fact, recent reports strongly indicated the involvement of ET and its receptor on oral cancer $(24,25)$. In addition, it was also reported that suppression of endothelinconverting enzyme-1 caused the inhibition of SCC proliferation (26). Our results, together with those reports, strongly suggest the importance of ET synthesis and its receptor-signalling pathway on oral SCC proliferation.

It is reported that phosphorylation of FAK is involved in the inhibition of apoptosis and promote cell growth in SCC cell lines $(15,18)$. FAK is a $125 \mathrm{kDa}$ non-receptor tyrosine kinase and an important regulator of cell survival, invasion, migration, and cell cycle progression $(15,18,20,21)$. FAK is functionally important in transducing intracellular messages that are associated with growth factor signalling $(15,18,20,21,27)$. The intracellular messages link p-FAK at $\mathrm{Tyr}^{925}$ to signalling pathways that activate MAPK cascades. In our present study, however, the inhibition of phosphorylation of FAK in SCCs treated with ET antagonists and siRNAs was not observed. In contrast, the inhibition of the phosphorylation of MEK and Erk by the treatment with ET antagonists and siRNAs was clearly observed. These results indicate that the inhibition of MAPK pathway by the suppression of ET receptor-signalling is due to the direct inhibition of MAPK pathway, but not through FAK pathway (Fig. $5 B)$. Several reports have indicated the coupling of ET receptorsignalling and MAPK pathway $(28,29)$. Our results agree with those reports and indicate that the mechanisms of the inhibition of cell growth by ET receptor-siRNAs and antagonists are, in part, due to the inhibition of MAPK pathway.

Reduction of dosage of anti-tumor drugs for cancer chemotherapy is clinically important to minimize the side effects, although the complete tumor cell death is required. Combined treatment of low concentration of ET receptorsiRNA $(20 \mathrm{nM})$ with low concentration of anti-tumor drug, cisplatin $(2.5 \mu \mathrm{M})$, drastically inhibited the cell growth of SAS in comparison to that in each single treatment. Cisplatin is extensively characterized as DNA damaging agent and the cytotoxicity of cisplatin is attributed to the ability to form inter and intra-strand nuclear DNA crosslinks $(30,31)$. In contrast, inhibition of cell growth by ET receptor-siRNAs presented in our study was mainly due to the direct inhibition of MAPK pathway. Therefore, those two pathways on growth inhibition are different. This difference of mechanisms between ET receptor-siRNA and cisplatin may lead to show synergistic effect on the inhibition of tumor cell growth (Fig. 5A and B). Our results indicate that the decrease in ET receptor levels in SCCs that strongly express ET receptors increases the sensitivity against chemotherapy, and that the siRNA for ET receptors combined with anti-tumor drugs might be a useful therapy to reduce the dosage of anti-tumor drugs.
In summary, we showed the overexpression of $\mathrm{ET}_{\mathrm{A}}$ and $\mathrm{ET}_{\mathrm{B}}$ in tumor cells of human primary lingual SCC tissues and cultured SCC cell lines, and suggest a potentially important role for ET receptor-signalling on the cell growth of human SCCs.

\section{Acknowledgements}

This study was supported in part by grants (21592357 to K.W., 20390471 to Y.K., and 21390535 to M.K.) from the Japanese Society for the Promotion of Science, and was supported by The Osaka Medical Research foundation for Intractable Diseases.

\section{References}

1. Yanagisawa M, Kurihara H, Kimura S, et al: A novel potent vasoconstrictor peptide produced by vascular endothelial cells. Nature 332: 411-415, 1988.

2. Inoue A, Yanagisawa M, Kimura S, et al: The human endothelin family: three structurally and pharmacologically distinct isopeptides predicted by three separate genes. Proc Natl Acad Sci USA 86: 2863-2867, 1989.

3. Davenport AP: International union of pharmacology. XXIX Update on endothelin receptor nomenclature. Pharmacol Rev 54: 219-226, 2002.

4. Kusserow $\mathrm{H}$ and Unger T: Vasoacitive peptides, their receptors and drug development. Basic Clin Pharmacol Toxicol 94: 5-12, 2004.

5. Ahmed SI, Thompson J, Coulson JM and Woll PJ: Studies on the expression of endothelin, its receptor subtypes, and converting enzymes in lung cancer and in human bronchial epithelium. Am J Respir Cell Mol Biol 22: 422-431, 2000.

6. Asham E, Shankar A, Loizidou M, et al: Increased endothelin-1 in colorectal cancer and reduction of tumor growth by ET(A) receptor antagonism. Br J Cancer 85: 1759-1763, 2001.

7. Zhang Y, Tang L, Su M, et al: Expression of endothelines and their receptors in nonmelanoma skin cancers. J Cutan Med Surg 10: 269-276, 2006

8. Spinella F, Rosano L, DiCastro V, Natali PG and Bagnato A: Endothelin-1 induces vascular endothelial growth factor by increasing hypoxia-inducible factor-1 alpha in ovarian carcinoma cells. J Biol Chem 277: 27850-27855, 2002.

9. Wulfing P, Kersting C, Tio J, et al: Endothelin-1-, endothelin-A-, and endothelin-B-receptor expression is correlated with vascular endothelial growth factor expression and angiogenesis in breast cancer. Clin Cancer Res 10: 2393-2400, 2004.

10. Boldrin L, Gisfredi S, Ursino S, et al: Expression of endothelin-1 is related to poor prognosis in non-small cell lung carcinoma. Eur J Cancer 41: 2828-2835, 2005.

11. Kandalaft LE, Facciabene A, Buckanovich RJ and Coukos G: Endothelin B receptor, a new target in cancer immune therapy. Clin Cancer Res 15: 4521-4528, 2009.

12. Goepfert H: Squamous cell carcinoma of the head and neck: past progress and future promise. CA Cancer J Clin 48: 195-198, 1998.

13. Okura M, Hiranuma T, Adachi T, et al: Induction chemotherapy is associated with an increase in the incidence of locoregional recurrence in patients with carcinoma of the oral cavity: results from a single institution. Cancer 82: 804-815, 1998.

14. Prince S and Bailey BM: Squamous carcinoma of the tongue: review. Br J Oral Maxillofac Surg 37: 164-174, 1999.

15. Masuda T, Wada K, Nakajima A, et al: Critical role of peroxisome proliferator-activated receptor $\gamma$ on anoikis and invasion of squamous cell carcinomas. Clin Cancer Res 11: 4012-4021, 2005.

16. Takahashi H, Fujita K, Fujisawa T, et al: Inhibition of peroxisome proliferator-activated receptor gamma activity in esophageal carcinoma cells results in a drastic decrease of invasive properties. Cancer Sci 97: 854-860, 2006.

17. Ishida H, Wada K, Masuda T, et al: Critical role of estrogen receptor on anoikis and invasion of squamous cell carcinoma. Cancer Sci 98: 636-643, 2007.

18. Nagata M, Wada K, Nakajima A, et al: Role of myeloid cell leukemia-1 on cell growth of squamous cell carcinoma. J Pharmacol Sci 110: 344-353, 2009. 
19. Kusayama M, Wada K, Nagata M, et al: Critical role of aquaporin 3 on growth of human esophageal and oral squamous cell carcinoma. Cancer Sci 102: 1128-1136, 2011.

20. Chen HC, Appeddu PA, Parsons JT, Hildebrand JD, Schaller MD and Guan JL: Interaction of focal adhesion kinase with cytoskeletal protein talin. J Biol Chem 270: 16995-16999, 1995.

21. Sieg DJ, Hauck CR, Ilic D, et al: FAK integrates growth-factor and integrin signals to promote cell migration. Nat Cell Biol 2 : 249-256, 2000

22. Zhang Z, Vuori K, Reed JC and Ruoslahti E: The alpha 5 beta 1 integrin supports survival of cells on fibronectin and up-regulates Bcl-2 expression. Proc Natl Acad Sci USA 92 6161-6165, 1995

23. Yamada KM and Geiger B: Molecular interactions in cell adhesion complexes. Curr Opin Cell Biol 9: 76-85, 1997.

24. Hoffman RR, Yurgel LS and Campos MM: Endothelins and their receptors as biological markers for oral cancer. Oral Oncol 46: 644-647, 2010

25. Hoffman RR, Yurgel LS and Campos MM: Evaluation of salivary endothelin-1 levels in oral squamous cell carcinoma and oral leukoplakia. Regulatory Peptide 166: 55-58, 2011.
26. Awano S, Dawson LA, Hunter AR, Turner AJ and Usmani BA: Endothelin system in oral squamous carcinoma cells: Specific siRNA targeting of ECE-1 blocks cell proliferation. Int J Cancer 118: 1645-1652, 2006.

27. Frish SM and Francis H: Disruption of epithelial cell-matrix interactions induces apoptosis. J Cell Boil 124: 619-626, 1994.

28. Bogoyevitch MA, Glennon PE, Andersson MB, et al: Endothelin-1 and fibroblast growth factors stimulate the mitogen-activated protein kinase signalling cascade in cardiac myocytes. J Biol Chem 269: 1110-1119, 1994.

29. Cramer H, Schmenger K, Heinrich K, et al: Coupling of endothelin receptors to the ERK/MAP kinase pathway. Eur J Biochem 268: 5449-5459, 2001

30. Meyers M, Hwang A, Wagner MW and Boothman DA: Role of DNA mismatch repair in apoptotic responses to therapeutic agents. Environ Mol Mutagen 44: 249-264, 2004.

31. Psyrri A and Fountzilas G: Advances in the treatment of locally advanced non-nasopharyngeal squamous cell carcinoma of the head and neck region. Med Oncol 23: 1-15, 2006. 